\title{
Differentiation of wholesale prices for organic agricultural products
}

\author{
Grigory Yazev $^{1}$, Taisiya Ryabova ${ }^{1, *}$ and Vyacheslav Zhenzhebir ${ }^{1}$ \\ ${ }^{1}$ Moscow state University of technology and management. K. G. Razumovsky, Zemlyanoy Val street, \\ 73, 109004, Moscow, Russia
}

\begin{abstract}
The urgency of the study is based on the fact that for a long time, there have been disputes in the scientific world about methods and models for determining the value of prices, on the basis of which the economic accessibility of various kinds of organic products depends. It is especially important to resolve the issue of setting prices for agricultural cooperatives, which have developed in the Russian market economy. The purpose of the study is to find a method for setting wholesale prices for organic products, the consumer demand for which has increased over the past two years and exceeded the level established by the Russian Academy of Medical Sciences. The following methods were used in the study: analytical, systemic, comparative, economic and mathematical, hypothetical, questionnaires, etc. The study conducted an excursus into the field of basic theories of determining prices created by scientists, on the basis of which it was concluded that there is no single approach to determining their values. The prices for organic agricultural products sold by large retailers are analyzed. Using a sample of closest prices of various agricultural producers, average wholesale prices for agricultural products were determined for three regions of the Central Federal District. As a result of the conducted study, the wholesale price for organic agricultural products (on the example of potatoes) purchased by wholesale distribution centers providing the needs of the population of Moscow and the Moscow region was substantiated.
\end{abstract}

\section{Introduction}

Differentiation of the price level for potatoes assumes that the cooperatives have the opportunity to sell the product in three scenarios: using the average value of the cost; at a high price in comparison with its average value; and also at a price that is less than its average. Thus, the commodity producer applying different variants of prices for potatoes depending on the variety, quality, volume of supply and demand, and the time of the year can plan the growth of the sale of potatoes and attraction of an additional contingent of customers.

At the same time, it is necessary to differentiate potatoes into two types - a priority one, which is washed and sold at a higher price because of its variety, quality, and in high demand among customers; and basic or traditional one, whose value differs from the average market

\footnotetext{
* Corresponding author: ryabova@mail.ru
} 
price. The relationship between the volume of sales and the effectiveness of stimulating intermediaries should be implemented through communication and pricing policies determined by the commodity producer. It is revealed that enterprises do not always use the most important mechanisms that promote the growth of potato sales and raise their own income. Most often, the price depends on the level of the most often set price, which is close to the average cost per district or region. Usually, such a price is determined on the basis of the sum of the cost of production and the level of profit, or depending on the own concept of development. In the markets, prices are formed, as a rule, spontaneously under the influence of the supply-demand ratio. The seller can dictate the terms of sale of goods in accordance with his strategy and decide which type of goods can ensure the greatest profit, and which - profits in a short time, which is possible when selling the product at a reduced price to obtain the necessary financial resources.

The price calculation is based on a number of factors accepted throughout the world: the uniqueness of the product, the period of preservation, the consumer utility, the actual prices on the market, the name of variety, etc. In addition to the basic price (in our case - price of potatoes), the use of differentiated prices is important.

\section{Materials and Methods}

In the process of study, the works of scientists were studied, which substantiated the impact of macroeconomic and microeconomic, internal and external factors on price formation.

Internal factors are reflected in the following categories: quality of work - "The formation of a rational structure of labor resources is the key aspect of raising the level of the country's development and ensuring food security" [1]; development strategy - "For economic development of the country, it is necessary that each organization defines a development strategy and continuously implements promising solutions. As the strategic problems, one can name the definition of the possibility of diversification and restructuring of the sphere of production, labor and management, strengthening the position in the market, enhancing the image of the organization" [2]; product competitiveness - "Low-quality products reduce the solvency of the population. To replenish its volume, additional quantities of food products are required. Along with that, the whole batch of produce will be withdrawn from the marketplace, which will entail additional economic and material losses for the organization" [3].

External factors: the development of the tax system - "The tax system should be improved in order to reduce financial pressure on agricultural enterprises, specify the tax base and reduce the current large number of taxes to budgets and extra-budgetary funds, differentiate existing taxes depending on regional production conditions" [4]; reforming the economy "Restructuring contributes to the formation of civilized methods of competition between commodity producers, to the reduction of risks and expansion of the range of products" [5]; complex development - "The implementation of a number of areas of development of competition for the customer has provided many enterprises of different countries with successful participation in the marketplace for a long time. Effective survival of individual enterprises in the market conditions and obtaining by them of profits sufficient for the production would give an opportunity to eventually raise the national economy" [6]; multivariate development scenarios - ... "development based on an optimistic, pessimistic, and most probabilistic scenario" [7]; formation of the knowledge base - "Every stage of social development must develop a system of competencies that ensure the balance of the internal and external environment of organizations. ... competence in relation to managers of various levels and ranks of management of the organization is a reflection of the totality of common sense, knowledge, skills, experience, and cultural behaviour" [8]; development forecast - "The forecasting of a strategy for improving the quality and competitiveness of products should be based on the following alternative approaches: comparison of the quality of products with the 
best domestic sample of similar products on the market at the moment; ... comparison of the quality of products with similar products at the world level; comparison of the quality of products with the products of a new sample produced in the world" [9].

It is established that the prices for potatoes depend on a number of the following differentiated factors:

- increase in prices for seeds, material and technical resources, organic fertilizers, means of protecting plants and tubers from pests, etc.

- introduction of new production technologies. The rise in prices for equipment and technologies for production of potatoes contributes to an increase in production costs and a reduction in its supply;

- forecasting of price increases. If the price increase is predicted, the sellers of potatoes reduce the supply of sales at this time in order to sale it in the next period at higher prices;

- forecasting of price reduction. If the decrease in prices is predicted, then sellers increase the volume and price of selling potatoes in order to increase the revenues;

- seasonality of harvesting. The price of potatoes, as a rule, decreases during the harvest period and increases in the winter months and the pre-sowing period;

- instability of natural and climatic conditions. Unfavourable weather conditions (frost, rain, drought) adversely affect yield, which causes a reduction in the supply of agricultural products;

- rising inflation. The price of potatoes due to rising prices for raw materials and material and technical resources is increasing in an appropriate amount;

- tax increase. The introduction of new rates and new taxes causes a reduction in the supply of potatoes;

- fluctuations and disparity in the prices of supply and demand. The discrepancy between the growth rates of prices for potatoes of commodity producers and sellers affects the price of supply.

The impact of the factors mentioned above leads to a change in the equilibrium price established as a result of their initial interaction. In this situation, the following scenarios are possible:

- Change in the volume of supply and the price of potatoes with a stable demand situation: growth or reduction in supply; change in demand and prices of potatoes with stable supply: growth or reduction in demand.

- Here are the main characteristics of the change in the price of potatoes, as well as the volume of demand and supply: reduction in demand with growth in supply; reduction in supply with growth in demand; reduction in both demand and supply; growth in demand and supply.

The choice of the pricing strategy is based on the following activities that contribute to the growth of sales:

- achievement of interest with cooperatives - commodity producers and other competitors of the agreed uniform price policy when selling potatoes in the WDC (wholesale distribution centre);

- regulation of the number of partners in the chain of commodity circulation - the more the number, the lower the price of potatoes and the higher the risk of all members of cooperatives;

- limitation of the terms of cooperation between cooperators and enterprises - when extending the term of contacts with one business partner in the sale of potatoes, the overall risk of large losses is higher;

- the compatibility of the spheres of activity and the interest in the coherence of adoption of a uniform price policy, the expansion of cooperation, the exchange of information, the cooperation of financial assets, the expansion of the range of products, etc .; 
- the lack of an integrated approach to the sale of products in the process of promotion to the market can lead to loss of goods and a reduction in income;

- availability of legal regulation of trade, contractual, and financial relationships between various cooperatives that sell potatoes in the WDC, etc.

Taking into account the organizational and economic conditions, the most acceptable form of creation and functioning of cooperatives is chosen, which, even with high inflation, helps partners (producers and enterprises) eliminate problems that prevent reduction of prices [10].

In the course of the study based on expert assessments, it is established that the following factors, which are stated in order of importance, are important factors depressing the profitability of agricultural producers:

- low wholesale prices of commodity producers when purchasing potatoes by the WDC that do not allow replenishing the invested costs and do not contribute stimulation of further growth of production;

- high growth rate of prices for machinery, spare parts, fertilizers, electricity, and other material and technical resources;

- imperfection of infrastructure, lack of information technology and robotics in the production, storage, processing, and sale of potatoes;

- presence of a network of intermediaries in the process of commodity circulation of potatoes from cooperatives to the WDC and other consumers;

- the territorial disconnection of technologically interconnected industries does not allow effective implementation of the enormous potential of the raw material base, meeting the needs of the region's population in the main types of food products in full and the required range;

- remoteness of potato producers from each other, which does not allow them to concentrate large wholesale consignments, create a material and technical base, purchase seeds and other resources at a single reduced price.

\section{Results}

To substantiate an acceptable price for the remaining period of 2018, the study analyzed various prices of potatoes. Thus, the comparison of prices for large stores in the capital indicates that they differ significantly. The lowest price for potatoes (12 rubles.) is in "Auchan" and the highest (24.9 rubles.) is typical for "Pyaterochka". For comparison, the table shows prices for products on the expensive market, where it was 60 rubles per $\mathrm{kg}$ (Table 1).

The analysis showed that the average wholesale prices for potatoes in Russia with a purchase volume of up to 20 tons as of December 22, 2017 were 11.0 rubles per $\mathrm{kg}$ without VAT. Over the next week, prices increased by $3.4 \%$ or 0.4 rubles, over the month - by $7.1 \%$, i.e. by 0.7 rubles; over three months - by $15.7 \%$ ( 1.6 rubles).

Along with this, based on the factual data of respondents from Moscow and Moscow region enterprises, prices for large commodity producers and individual entrepreneurs were substantiated. Analysis of the data made it possible to establish that the wholesale price of potatoes ranges from 7 to 14 rubles on average.

Table 1. Monitoring of vegetable prices in Moscow.

\begin{tabular}{|l|c|c|c|c|c|}
\hline Name & Magnit & Pyaterochka & Auchan & Diksi & Expensive market \\
\hline Potatoes & 21,30 & 24,90 & $12^{* *}$ & 16,7 & 60 \\
\hline White cabbage & 14,90 & 14,90 & 13 & 14,80 & 100 \\
\hline Unwashed beetroot & 13,60 & 12,90 & 13,90 & 13,50 & 50 \\
\hline Washed beetroot & 32,60 & 42,90 & 29,70 & 44,90 & 150 \\
\hline
\end{tabular}


Due to the lack of differentiated information on the prices of cooperatives for potatoes from regional statistical offices in Smolensk, Lipetsk, and Tambov regions, economic entities that sell potatoes were identified, who took on the role of respondents. In total, 140 respondents were selected from the regions: Smolensk - 45 respondents, Lipetsk - 49 respondents, Tambov - 46 respondents (Table 2). To substantiate the price, various potato varieties of 5 th caliber (size) were analyzed as the most acceptable for the residents of the capital.

As can be seen from the data in Table 3,16 commodity producers $(7+1+8)$ offer to buy potatoes at a price of 8 rubles; 24 - at a price of 9 rubles; 22 - at a price of 10 rubles; 21 - at a price of 11 rubles; 18 - at a price of 12 rubles; 3 business entities - at a price of 13 rubles per $\mathrm{kg}$. The modal value of the price of elite potatoes in wholesale sales in the Smolensk region is 21 rubles per kg., Lipetsk region - 20 rubles per kg., Tambov region -25 rub per kg.

Using the method of determining the weighted average values by the number of enterprises and the wholesale weight of potatoes from 1.5 to 20 tons, the following data were obtained:

Smolensk region $-8 \times 7+9 \times 5+10 \times 7+11 \times 14+12 \times 6=385: 38=10,1 \mathrm{rub} / \mathrm{kg}$.

Lipetsk region $-8 \times 1+9 \times 11+10 \times 9+11 \times 1+12 \times 6=280: 28=10,0 \mathrm{rub} / \mathrm{kg}$.

Tambov region $-8 \times 8+9 \times 8+10 \times 6+11 \times 6+12 \times 7=346: 36=9,6 \mathrm{rub} / \mathrm{kg}$.

Table 2. Differentiation of wholesale prices for potatoes of $5^{\text {th }}$ caliber in Moscow and Moscow region.

\begin{tabular}{|l|l|l|l|}
\hline \multicolumn{1}{|c|}{ Seller organization } & Price, rub/kg & \multicolumn{1}{c|}{ Seller organization } & \multicolumn{1}{c|}{$\begin{array}{c}\text { Price, } \\
\text { rub/kg }\end{array}$} \\
\hline 1. Nanolend LLC & 16,5 & 1. Individual entrepreneur & 8,5 \\
\hline 2. BTK LLC & 19 & 2. Individual entrepreneur & 14 \\
\hline 3. Spetstekhtrance LLC & 16 & 3. Individual entrepreneur & 11,5 \\
\hline 4. Danik LLC & 22 & 4. Individual entrepreneur & 14 \\
\hline 5. Optima LLC & 7 & 5. Individual entrepreneur & 10 \\
\hline 6. 8 Potok LLC & 10 & 6. Individual entrepreneur & 12 \\
\hline 7. Agrotvist LLC & 14 & 7. Individual entrepreneur & 14 \\
\hline 8. Hermes Food LLC & 12 & 8. Individual entrepreneur & 10 \\
\hline 9. Tradepack-K LLC & 14 & 9. Individual entrepreneur & 9 \\
\hline 10. Fresh Import LLC & 7 & 10. Individual entrepreneur & 9 \\
\hline Average & 13,7 & 11. Individual entrepreneur & 13 \\
\hline 1. Individual entrepreneur & 8,5 & 12. Individual entrepreneur & 8 \\
\hline 2. Individual entrepreneur & 14 & 13. Individual entrepreneur & 14 \\
\hline 3. Individual entrepreneur & 11,5 & 14. Individual entrepreneur & 16 \\
\hline 4. Individual entrepreneur & 14 & 15. Individual entrepreneur & 15 \\
\hline 5. Individual entrepreneur & 10 & 16. Individual entrepreneur & 12 \\
\hline 6. Individual entrepreneur & 12 & Average & 13,5 \\
\hline 7. Individual entrepreneur & 14 & & \\
\hline 8. Individual entrepreneur & 10 & & \\
\hline 9. Individual entrepreneur & 9 & & \\
\hline 10. Individual entrepreneur & 9 & & \\
\hline 11. Individual entrepreneur & 13 & & \\
\hline 12. Individual entrepreneur & 8 & & \\
\hline 13. Individual entrepreneur & 14 & & \\
\hline 14. Individual entrepreneur & 16 & & \\
\hline 15. Individual entrepreneur & 15 & & \\
\hline 16. Individual entrepreneur & 12 & & \\
\hline Average & 13,5 & & \\
\hline & & & \\
\hline
\end{tabular}


In addition, based on the obtained values of the actual sale price of potatoes by various commodity producers, the number of which was from 45 in the Smolensk region to 49 in Lipetsk region, the average price for potatoes sold at wholesale was determined. In the Smolensk and Lipetsk regions, the average price is about 10 rubles per kg., and in the Tambov region the price was 9.6 rubles per $\mathrm{kg}$. Thus, it is established that in three regions under the study, the wholesale price of potatoes can be, on average, about 10 rubles per kg. (Table 3).

Table 3. Determination of the prices of potato producers by regions under the study.

\begin{tabular}{|c|c|c|c|}
\hline \multirow{2}{*}{ Potato price interval, rub. } & \multicolumn{3}{|c|}{$\begin{array}{c}\text { Number of objects that declared this value in the regions of } \\
\text { the Central Federal District, units. }\end{array}$} \\
\cline { 2 - 4 } & Smolensk & Lipetsk & Tambov \\
\hline 8 & 7 & 1 & 8 \\
\hline 9 & 5 & 11 & 8 \\
\hline 10 & 7 & 9 & 6 \\
\hline 11 & 14 & 1 & 7 \\
\hline 12 & 5 & 6 & 1 \\
\hline 13 & 1 & 1 & 6 \\
\hline $13,5-15$ (elite) & 5 & 13 & 9,6 \\
\hline $16-25$ & 1 & 7 & 25 \\
\hline Average of $8-12$ & 10,1 & 10,0 & 20 \\
\hline Modal value & 21 & & \\
\hline
\end{tabular}

It is revealed that since 2017, local managers can themselves form varieties of potatoes of cooperators by consignments for purchases. It is local managers who will make decisions on the selection of the variety and caliber of potatoes, conclude agreements with the WDC. At the same time, the contract should be adapted to the conditions of cooperators: to be more accessible for understanding, to contain the basic parameters of sale and prices.

Currently, about $60 \%$ of potato varieties are formed by regional structures. Such development of the sphere of interaction of regional local organizations will be aimed at meeting the needs of the population, increasing the competitiveness of the product, and expanding the assortment policy.

At the end of last year, contracts were signed with more than 100 local suppliers. "Auchan" is the most efficient network operating in Russia. Changes in the procurement system make it possible to improve the range of agricultural products.

\section{Conclusion}

On the basis of experimental data obtained through the survey of commodity producers, surveys of large wholesale distribution centers on the establishment of prices for potatoes, generalization and analysis of collected information, it was established that the definition of a differentiated reasonable price depends on the volume of supply of the consignment, quality and variety of potatoes, remoteness of the region from consumers, storage conditions, and type of equipment. The study made it possible to establish a reasonable wholesale price for the purchase of potatoes in three regions at the level of 10-11 rubles per kilogram. The supply of potatoes from Smolensk, Lipetsk, and Tambov regions due to the remoteness of commodity producers from each other and the inability to quickly organize the formation of a large consignment cannot fully satisfy the needs of residents of Moscow and the Moscow region. It is established that the Bryansk region is the leader in the production of potatoes and its storage conditions. Therefore, it is advisable to carry out additional study of the potato price level and delivery conditions from the Bryansk region to the Moscow region. 


\section{References}

1. V.V. Gusev, Ekonomika sel'skohozyajstvennyh i pererabatyvayushchih predpriyatij 2, 28-29 (2009)

2. V.V. Gusev, N.V. Ryabova, Ekonomicheskie nauki 11(48), 35-39 (2008)

3. V.N. Ivanova, Ekonomika, trud, upravlenie v sel'skom hozyajstve 4, 20-24 (2011)

4. E.V. Minaeva, Ekonomika i predprinimatel'stvo 1(3), 427-430 (2014)

5. T.F. Ryabova, Ekonomika i predprinimatel'stvo 6(47), 609-613 (2014)

6. A.S. Chizhik, Ekonomika i predprinimatel'stvo 1(3), 434-438 (2014)

7. G.V. Yazev, Uchenye zapiski SGAKS 1, 136-140 (2017)

8. A.A. Anfinogentova, M.N. Dudin, N.V. Lyasnikov, O.D. Protsenko, Economy of Region 14, 638-650 (2018), doi:10.17059/2018-2-24

9. V.M. Borovkov, L.V. Zysin, V.V. Sergeev, Izvestiya Akademii Nauk. Energetika, 1324 (2002)

10. A. Fedyukhin, I. Sultanguzin, A. Gyul'Maliev, V. Sergeev, Eurasian ChemicoTechnological Journal 19, 245-253 (2017), doi:10.18321/ectj669 